\title{
HEMATOLOGICAL AND BLOOD PLASMA BIOCHEMICAL CONSTITUENTS OF ONE HUMPED CAMEL (Camelus dromedaries) IN RELATION TO SOME PHYSIOLOGICAL, NUTRITIONAL AND PARASITOLOGICAL CONDITIONS
}

\author{
Y. M. Hafez
}

Department of Animal Production, Faculty of Agriculture, University of Cairo, Giza, Egypt

\section{SUMMARY}

Three separate experiments were conducted using a total of 46 camels to study the changes in camel blood hematology and biochemistry as affected by some physiological, nutritional and parasitological factors. The first experiment included 18 healthy male camels divided equally into three groups (one year, 3-5 years and 815 years old). The second experiment included 12 healthy mature camels (8-15 years) divided into three groups (6 male camels and 3 dry non pregnant and 3 non lactating pregnant she-camels).The third experiment included the remaining 16 peripubertal (3-5 years) male camels assigned equally to four groups [healthyadequately fed (control, $\left.G_{1}\right)$, prolonged poor grazing $\left(G_{2}\right)$, chronic mange infection $\left(G_{3}\right)$ and both as $\left.G_{2}+G_{3}\right]$.

Results indicated that all studied blood hematological parameters decreased gradually with the advancement of age $(P<0.05)$ except TLC differentiation that was not affected. Blood plasma TP, albumin and globulin increased $(P<0.05)$ with age while plasma glucose showed a reversed trend. Activities of AST and ALT liver enzymes were not affected by age but total bilirubin decreased $(P<0.05)$ with age. Young camels had lower $(P<0.05)$ calcium and phosphorus than peripubertal or mature camels but magnesium, plasma iron, copper and zinc were not affected by age.

Male camels showed higher $(P<0.05)$ values in all studied hematological parameters than females either pregnant or not. Pregnant dry she-camel had higher hematological parameters than the non pregnant dry she-camels. Male camels had higher TP, albumin and globulin than females either pregnant or not. Pregnancy had no significant effect on the studied plasma biochemical constituents. Also, plasma minerals were not significantly affected by either sex nor pregnancy.

Prolonged poor grazing exerted negative effects $(P<0.05)$ on the studied hematological parameters which increased in magnitude in association with mange infection, except TLC which showed an increase $(P<0.05)$. TLC differentiation showed that poor grazing when combined with mange infection reduced the percent of $N$ type but increased E, $M$ and L types in peripubertal male camels. Each poor grazing or mange infection caused a reduction in TP, Albumin, Globulin, A/G ratio and glucose in blood plasma. Such an effect increased when poor grazing was associated with mange infection. Activities of both liver enzymes (AST and ALT) and T. bilirubin showed the opposite effect. Plasma $\mathrm{Ca}, \mathrm{P}, \mathrm{Mg}$, and $\mathrm{Cu}$ were not affected by the above mentioned effectors while plasma Fe and $\mathrm{Zn}$ were adversely affected.

Issued by The Egyptian Society of Animal Production 
It is concluded that the physiological status and the studied adverse effects cause major changes in the studied blood hematological and biochemical parameters of camels.

Keywords: Camel, hematology, blood biochemistry

\section{INTRODUCTION}

Camel (Camelus dromedaries) is an important component of the desert ecosystem. The total world camel population was estimated to be 19.334 million. Out of which Africa has 15.124 million (78.22\%). Developing countries have $99.03 \%$ of this camel population. Furthermore, camel census in Egypt is estimated to be 120 thousands, which is $0.62 \%$ of the total world population (FAO, 2001).

In addition, camel is considered an important meat-producing animal. The amount of camel meat in Egypt was estimated as 36800 ton in 2004, which represents $5.8 \%$ of the total amount of red meat (General Authority of Veterinary Services, 2004).

Blood is an index for several metabolic processes of the body and could be a reliable indicator reflecting the status of the functioning organs of the body and health, hence productivity of the animal. On the other hand, hematological and biochemical determination of blood constituents is considered important information in relation to age, sex, pregnancy, nutritional status and health.

Therefore, the present study aimed to determine the values of several hematological and biochemical blood parameters in one humped camel and the extent to which age, sex, pregnancy, prolonged poor grazing and chronic mange infection affect these parameters.

\section{MATERIALS AND METHODS}

The present work was conducted at Al-Hagana Administration (Cairo suburban), farm at Cairo-Alexandria desert road and Animal Physiology Lab., Faculty of Agriculture, Cairo University, Egypt.

\section{1-Camels}

Three separate experiments each lasted for two months were conducted using a total of 46 camels. The first experiment included 18 healthy male camels, which were divided into three equal groups according to their age (one year, 3-5 years and 8- 15 years). They all were adequately fed.

The second experiment included another 12 healthy mature camels (8- 15 years) divided into three groups (6 male camels, 3 dry- not pregnant she-camels and 3 pregnant she-camels). These animals were adequately fed (1\% of body weight barely grains + ad libitum intake of ground nut hay).

The third experiment included another 16 peripubertal male camels (3- 5 years) which were assigned to four equal groups (control, prolonged poor grazing, chronic external parasite infection (mange) and prolonged poor grazing + chronic external parasite infection, mange). The control camels were healthy and adequately fed [complete feed mixture at $1 \%$ of body weight + Berseem (Trifolium alexandrinum) 
hay at $2 \mathrm{~kg} /$ day + rice straw (ad libitum)] while the poor grazing group did not receive any feeds except grazing on naturally grown scattered desert plants for three months pre-experiment till the end of the research. The external parasite infected group suffered from mange three months before the start of the experiment till the end of the research. The combined poor grazing and mange infected group suffered from both conditions for the same period.

Experimental camels were considered young, peripubertal or mature according to the dentition formula given by Rabagliati (1924) cited in Al-Qarawi et al. (2000) who stated that young ( $\leq$ one year old), peripubertal ( $3-5$ years) and mature ( $>6$ years and $<15$ years).

Water was offered to all camels once daily (7 a.m.) for ad libitum consumption except the day of blood sampling was offered at (10 a.m.). Experimental camels were kept at night in open shelters.

\section{2-Blood sample collection and analysis}

Blood samples were withdrawn from all experimental camels fortnightly (at 9 a. m.) before morning drinking and feeding or grazing. Blood samples were allowed to flow gently from the jugular vein into clean-dry labeled heparinized $10 \mathrm{ml}$ tubes. These samples were used in the same day for the examination of the blood total erythrocytes count ( TEC) and total leuckocytes count ( TLC) were done according to (Feldman et al, 2000) Packed cell volume (PCV: Frankle and Reitman, 1963) and hemoglobin (Hb: Benjamin, 1965). For the differential leukocyte count, three blood smears were taken from each blood sample and stained with Geimsa (Bancroft et al., 1996).

The mean corpuscular volume (MCV), mean corpuscular haemoglobin (MCH) and mean corpuscular haemoglobin concentration (MCHC) were determined according to Wintrobe et al. (1976)

$$
\begin{aligned}
& \text { MCV }(\mathrm{fl})=(\mathrm{PCV}(\%) \times 10) / \mathrm{TEC}\left(\times 10^{12} / \mathrm{L}\right) \\
& \mathrm{MCH}(\mathrm{pg})=(\mathrm{Hb}(\mathrm{g} / \mathrm{dl}) \times 10) / \mathrm{TEC}(\mathrm{x} 1012 / \mathrm{L}) \\
& \operatorname{MCHC}(\%)=(\mathrm{Hb}(\mathrm{g} / \mathrm{dl}) \times 100) / \mathrm{PCV}(\%)
\end{aligned}
$$

Blood plasma was separated by centrifugation $(3000 \mathrm{rpm} / 20$ minutes $)$ using Pasteur pipette. This plasma was kept frozen at $-20{ }^{\circ} \mathrm{C}$ for subsequent determination of total protein (TP: Henry et al., 1974), albumin (alb: Doumas et al., 1971), glucose (Bahram and Trinder, 1972), total bilirubin (Sherlock, 1951), aspartate amino transferase (AST) and alanine amino transferase (ALT) Reitman and Frankle (1957), but globulin (Glob) and albumin globulin ratio $(\mathrm{A} / \mathrm{G})$ were calculated.

Apart of blood plasma was ashed to determine the following minerals Calcium (Ca), inorganic phosphorus $(\mathrm{P})$ and Magnesium $(\mathrm{Mg}$ ) according to (Tietz, 1983), but for the determination of copper (CU), iron (Fe) and Zinc ( $\mathrm{Zn})$ the atomic absorption spectrophotometer (Unicam 969 AA Spectrometer) was used according to (Campbell et al., 1999)

\section{Statistical analysis}

The data set was subjected to analysis of variance as repeated measurements (split plot in time) according to Neter et al. (1985) using SAS (SAS, 1998). Differences among means were tested using Duncan, 1955. Three different statistical models were utilized. The first model was to study the changes in camel blood hematology and biochemistry as affected by camel age. 
$Y_{i j}=\mu+A_{i}+E_{i j}$

Whereas: $Y_{i j}=$ Observation measured, $\mu=$ Overall mean, $A_{i}=$ camel age $(i=1$ one year group, $\mathrm{i}=2$ (3-5 years) group, $\mathrm{i}=3$ (8-15 years) group), $\mathrm{E}_{\mathrm{ij}}=$ Experimental error assumed to be randomly distributed $\left(0, \sigma_{\mathrm{e}}^{2}\right)$.

The second model was to study the changes in mature camel blood hematology and biochemistry as affected by different physiological conditions.

$\mathrm{Y}_{\mathrm{ij}}=\mu+\mathrm{P}_{\mathrm{i}}+\mathrm{E}_{\mathrm{ij}}$

Whereas: $\mathrm{Y}_{\mathrm{ij}}=$ Observation measured, $\mu=$ Overall mean, $\mathrm{P}_{\mathrm{i}}=$ physiological condition ( $\mathrm{i}=1$ male group, $\mathrm{i}=2$ female dry non pregnant group, $\mathrm{i}=3$ female dry pregnant group), $E_{i j}=$ Experimental error assumed to be randomly distributed $\left(0 \sigma_{\mathrm{e}}{ }^{2}\right)$.

The third model was to study the changes in peripubertal camel blood hematology and biochemistry as affected by nutrition and health status.

$\mathrm{Y}_{\mathrm{ij}}=\mu+\mathrm{N}_{\mathrm{i}}+\mathrm{E}_{\mathrm{ij}}$

Whereas: $Y_{i j}=$ Observation measured, $\mu=$ Overall mean, $\mathrm{N}_{\mathrm{i}}=$ nutrition and health status ( $i=1$ healthy normally fed group, $i=2$ poor grazing group, $i=3$ external parasite infected group, $\mathrm{i}=4$ poor grazing and ex. Parasite group), $\mathrm{E}_{\mathrm{ij}}=$ Experimental error assumed to be randomly distributed $\left(0, \sigma_{\mathrm{e}}{ }^{2}\right)$.

\section{RESULTS AND DISCUSSION}

\section{1-Effect of age}

Hematological blood parameters of male camels in relation to age are shown in Table 1. Total erythrocyte count (TEC) was the highest in young camels (1 year), decreased in peripubertal camels (3- 5 years), while reached its minimal values in mature camels $(8-15$ years $),(p<0.05)$. The same trend was observed for blood hemoglobin, PCV, MCV, MCH, MCHC and TLC $(\mathrm{p}<0.05)$. These results are in agreement with those reported by Zoethout and Tuttle (1950) in human and Wintrobe et al. (1976) in animals who both reported that young mammals had considerable higher hematological values than adults.

Table 1. Mean \pm SE of Some blood parameters of male camels at different ages

\begin{tabular}{lccc}
\hline Blood & \multicolumn{3}{c}{ Camel Age } \\
parameters & 1 year & 3-5 years & 8- 15 years \\
\cline { 2 - 4 } TEC x 10 & $8.130^{\mathrm{a}} \pm 0.12$ & $6.711^{\mathrm{b}} \pm 0.14$ & $6.256^{\mathrm{c}} \pm 0.16$ \\
$\mathrm{Hb}, \mathrm{g} / \mathrm{dl}$ & $14.54^{\mathrm{a}} \pm 0.33$ & $12.30^{\mathrm{b}} \pm 0.28$ & $10.93^{\mathrm{c}} \pm 0.24$ \\
$\mathrm{PCV} \%$ & $29.28^{\mathrm{a}} \pm 0.40$ & $27.94^{\mathrm{b}} \pm 0.34$ & $26.98^{\mathrm{c}} \pm 0.30$ \\
$\mathrm{MCV}, \mathrm{fl}$ & $46.86^{\mathrm{a}} \pm 0.68$ & $41.71^{\mathrm{b}} \pm 0.59$ & $33.30^{\mathrm{c}} \pm 0.51$ \\
$\mathrm{MCH}$, pg & $23.24^{\mathrm{a}} \pm 0.35$ & $18.34^{\mathrm{b}} \pm 0.31$ & $13.46^{\mathrm{c}} \pm 0.27$ \\
$\mathrm{MCHC} \%$ & $49.63^{\mathrm{a}} \pm 0.91$ & $44.02^{\mathrm{b}} \pm 0.79$ & $40.50^{\mathrm{c}} \pm 0.68$ \\
TLC x 10 & $11.008^{\mathrm{a}} \pm 0.34$ & $10.797^{\mathrm{a}} \pm 0.29$ & $9.226^{\mathrm{b}} \pm 0.26$ \\
TLC differentiation & & & \\
N \% & $40.11^{\mathrm{a}} \pm 1.84$ & $41.00^{\mathrm{a}} \pm 1.60$ & $42.68^{\mathrm{a}} \pm 1.38$ \\
E \% & $4.67^{\mathrm{a}} \pm 0.46$ & $5.08^{\mathrm{a}} \pm 0.40$ & $5.13^{\mathrm{a}} \pm 0.34$ \\
B \% & $0.00^{\mathrm{a}} \pm 0.0$ & $0.17^{\mathrm{a}} \pm 0.06$ & $0.00^{\mathrm{a}} \pm 0.0$ \\
M \% & $4.44^{\mathrm{a}} \pm 0.41$ & $3.17^{\mathrm{b}} \pm 0.35$ & $3.18^{\mathrm{b}} \pm 0.30$ \\
L \% & $50.78^{\mathrm{a}} \pm 1.89$ & $50.58^{\mathrm{a}} \pm 1.63$ & $49.00^{\mathrm{a}} \pm 1.41$ \\
\hline
\end{tabular}

Means within the same row having different superscripts differ significantly $(\mathrm{P}<0.05)$ 
Inspection of leukocyte differentiation indicated that neutrophils $(\mathrm{N})$, eosinophils (E), basophils (B), and lymphocytes (L) types were not affected by the tested camel age, while monocytes $(M$ type was higher $(p<0.05)$ in young camels compared to the other two examined ages.

Blood plasma constituents of male camels as affected by age are presented in Table 2. Total protein concentration was the lowest in young camels, increased in peripubertal camels, while it was the maximum in mature camels $(\mathrm{P}<0.05)$. This was mainly due to a similar trend of increased plasma globulin concentration with age and in part due to an increase in plasma albumin in mature camels. Plasma A/G ratio was similar in young and mature camels being lower $(\mathrm{P}<0.05)$ in peripubertal camels. These results are in agreement with those of Chaudhary, et al. (2003) who observed that serum total proteins increased with age of camel due to progressive increase in globulins due to lymphoid system maturity. The same authors also observed that plasma albumin was higher in adult camels than in camel calves due to higher liver activities.

Table 2. Mean \pm SE of some blood plasma constituents of male camels

\begin{tabular}{lccc}
\hline Plasma constituents & \multicolumn{3}{c}{ Camel age } \\
\cline { 2 - 4 } & $\mathbf{1}$ year & $\mathbf{3 - 5}$ years & $\mathbf{8 - 1 5}$ years \\
\hline Total Protein, g/dl & $6.31^{\mathrm{a}} \pm 0.40$ & $7.54^{\mathrm{b}} \pm 0.34$ & $9.92^{\mathrm{c}} \pm 0.30$ \\
Albumin, g/dl & $3.03^{\mathrm{a}} \pm 0.30$ & $3.27^{\mathrm{a}} \pm 0.25$ & $4.47^{\mathrm{b}} \pm 0.22$ \\
Globulin, g/dl & $3.04^{\mathrm{a}} \pm 0.39$ & $4.51^{\mathrm{b}} \pm 0.34$ & $5.45^{\mathrm{b}} \pm 0.29$ \\
$\mathrm{~A} / \mathrm{G}$ ratio & $1.11^{\mathrm{a}} \pm 0.14$ & $0.69^{\mathrm{b}} \pm 0.21$ & $0.94^{\mathrm{b}} \pm 0.10$ \\
Glucose, mg/dl & $136.28^{\mathrm{a}} \pm 6.02$ & $88.59^{\mathrm{b}} \pm 5.21$ & $64.88^{\mathrm{c}} \pm 4.51$ \\
$\mathrm{AST}, \mathrm{RFU}$ & $80.11^{\mathrm{a}} \pm 2.2$ & $79.08^{\mathrm{a}} \pm 1.9$ & $79.81^{\mathrm{a}} \pm 1.67$ \\
ALT, RFU & $28.11^{\mathrm{a}} \pm 1.65$ & $29.25^{\mathrm{a}} \pm 1.43$ & $32.25^{\mathrm{a}} \pm 1.24$ \\
Total bilirubin, g/dl & $1.73^{\mathrm{a}} \pm 0.07$ & $1.57^{\mathrm{a}} \pm 0.06$ & $1.38^{\mathrm{b}} \pm 0.05$ \\
$\mathrm{Minerals} \mathrm{contents}$ & & & \\
$\mathrm{Ca}, \mathrm{mg} / \mathrm{dl}$ & $8.57^{\mathrm{a}} \pm 0.66$ & $11.45^{\mathrm{b}} \pm 0.58$ & $11.27^{\mathrm{b}} \pm 0.50$ \\
$\mathrm{P}, \mathrm{mg} / \mathrm{dl}$ & $5.12^{\mathrm{a}} \pm 0.29$ & $5.70^{\mathrm{b}} \pm 0.26$ & $6.45^{\mathrm{ab}} \pm 0.34$ \\
$\mathrm{Mg}, \mathrm{mg} / \mathrm{dl}$ & $2.35^{\mathrm{a}} \pm 0.15$ & $1.82^{\mathrm{b}} \pm 0.13$ & $2.02^{\mathrm{ab}} \pm 0.11$ \\
$\mathrm{Fe}, \mu \mathrm{g} / \mathrm{dl}$ & $46.10^{\mathrm{a}} \pm 0.73$ & $52.30^{\mathrm{a}} \pm 0.64$ & $53.10^{\mathrm{a}} \pm 0.55$ \\
$\mathrm{Cu}, \mu \mathrm{g} / \mathrm{dl}$ & $48.00^{\mathrm{a}} \pm 1.80$ & $87.00^{\mathrm{a}} \pm 0.16$ & $65.00^{\mathrm{a}} \pm 1.30$ \\
$\mathrm{Zn}, \mu \mathrm{g} / \mathrm{dl}$ & $84.00^{\mathrm{a}} \pm 2.00$ & $76.00^{\mathrm{a}} \pm 0.18$ & $65.00^{\mathrm{a}} \pm 1.50$ \\
\hline $\mathrm{Means}$ within the sam & & &
\end{tabular}

Means within the same row having different superscripts differ significantly $(\mathrm{P}<0.05)$

Plasma glucose concentration was the highest $(\mathrm{P}<0.05)$ in young camels, decreased $(\mathrm{P}<0.05)$ as camels advanced in age as to be the minimum in mature camels. These results can be explained by the fact that in the early stages of camel life the rumen is not mature.

Plasma activities of transaminases (AST \& ALT) were not affected by the studied camel ages, while total bilirubin tended to be decreased with advancing of camel age as to be the lowest $(\mathrm{P}<0.05)$ at maturity. These results are in accordance with those of Sarwar et al. (2004) who observed that plasma AST activity was not affected by camel age (from 4 years to over than 7 years old).

Plasma calcium and phosphorus were lower $(\mathrm{P}<0.05)$ in young camels than 
peripubertal or mature camels. Magnesium concentration in plasma was higher $(\mathrm{P}<0.05)$ in young camels compared to peripubertal camels with a tendency to be higher than the mature camels.

Plasma iron and copper tended to increase, while plasma zinc tended to decrease with the advancement of age of the camels. Such higher zinc concentration observed in young camels may be related to the necessity for zinc- binding enzymes for growth and development (Mohamed, 2004).

\section{Effect of sex and pregnancy}

Hematological parameters of mature camels in relation to sex and pregnancy are presented in Table 3. Male camels showed higher $(\mathrm{P}<0.05)$ values of blood TEC, $\mathrm{Hb}, \mathrm{PCV}$ and $\mathrm{MCHC}$ compared to females, while the reverse was observed for MCV and TLC values. The value of MCH was similar in both sexes. Results of Table 3 also indicated that there were no differences related to sex in all types of leukocytes.

Table 3. Mean $\pm \mathrm{SE}$ of Some hematological parameters of mature camels (8-15 years) as affected by sex and pregnancy

\begin{tabular}{lccc}
\hline & \multicolumn{3}{c}{ Physiological conditions } \\
\cline { 2 - 4 } Blood parameters & Male & Female dry not pregnant & Female pregnant \\
\cline { 2 - 4 } TEC x $10^{6}$ & $8.130^{\mathrm{a}} \pm 0.16$ & $6.278^{\mathrm{b}} \pm 0.20$ & $7.523^{\mathrm{c}} \pm 0.18$ \\
$\mathrm{Hb}, \mathrm{g} / \mathrm{dl}$ & $10.93^{\mathrm{a}} \pm 0.26$ & $8.61^{\mathrm{a}} \pm 0.30$ & $10.30^{\mathrm{b}} \pm 0.30$ \\
$\mathrm{PCV} \%$ & $26.98^{\mathrm{a}} \pm 0.36$ & $23.95^{\mathrm{a}} \pm 0.73$ & $26.96^{\mathrm{b}} \pm 0.66$ \\
$\mathrm{MCV}(\mathrm{fl})$ & $33.30^{\mathrm{a}} \pm 0.44$ & $38.14^{\mathrm{a}} \pm 0.50$ & $35.88^{\mathrm{b}} \pm 0.50$ \\
$\mathrm{MCH}(\mathrm{pg})$ & $13.75^{\mathrm{a}} \pm 0.30$ & $13.80^{\mathrm{a}} \pm 0.60$ & $13.70^{\mathrm{a}} \pm 0.50$ \\
MCHC\% & $40.50^{\mathrm{a}} \pm 0.89$ & $36.24^{\mathrm{a}} \pm 1.70$ & $38.20^{\mathrm{a}} \pm 1.50$ \\
TLC x 10 & $9.230^{\mathrm{a}} \pm 0.30$ & $11.380^{\mathrm{a}} \pm 0.60$ & $9.653^{\mathrm{a}} \pm 0.50$ \\
TLC differentiation & & & \\
$\mathrm{N} \%$ & $42.69^{\mathrm{a}} \pm 1.30$ & $43.00^{\mathrm{a}} \pm 1.90$ & $43.83^{\mathrm{a}} \pm 1.70$ \\
E\% & $5.13^{\mathrm{a}} \pm 0.35$ & $5.60^{\mathrm{a}} \pm 0.60$ & $5.83^{\mathrm{a}} \pm 0.50$ \\
$\mathrm{~B} \%$ & $0.00^{\mathrm{a}} \pm 0.0$ & $0.20^{\mathrm{a}} \pm 0.10$ & $0.00^{\mathrm{a}} \pm 0.0$ \\
M\% & $3.19^{\mathrm{a}} \pm 0.25$ & $3.80^{\mathrm{a}} \pm 0.50$ & $3.67^{\mathrm{a}} \pm 0.50$ \\
L\% & $49.0^{\mathrm{a}} \pm 1.40$ & $47.40^{\mathrm{a}} \pm 2.0$ & $46.70^{\mathrm{a}} \pm 1.8$ \\
\hline
\end{tabular}

Means within the same row having different superscripts differ significantly $(\mathrm{P}<0.05)$

The data also indicated that the TEC, Hb, PCV, and MCHC were higher $(\mathrm{P}<0.05)$ in pregnant females than non pregnant while TLC showed reversed trend. Differentiation of leucocytes showed a non-significant trend due to pregnancy and sex.

Blood plasma biochemical constituents of mature camels as affected by sex and pregnancy are showed in Table 4. Plasma total protein and albumin concentrations were higher $(\mathrm{P}<0.05)$ in males than females. However, there were no differences between males and females in plasma globulin concentration or $\mathrm{A} / \mathrm{G}$ ratio. Moreover, there were no differences between male and female camels in blood plasma glucose, AST, ALT, total bilirubin, $\mathrm{Ca}, \mathrm{P}, \mathrm{Mg}, \mathrm{Fe}, \mathrm{Cu}$ or $\mathrm{Zn}$. These results are in agreement with those of Sarwar et al. (2004), who observed no existing differences in AST activity or $\mathrm{Ca}$ concentration of blood plasma between mature male and female camels. Furthermore, Mohamed (2004) observed no effect of sex on the content of $\mathrm{Cu}$ and $\mathrm{Zn}$ in plasma of camels. On the other hand there were no differences $(\mathrm{P}<0.05)$ 
between pregnant and non-pregnant she-camels in any of the studied plasma biochemical constituents. In agreement with the present results, Sarwar et al. (2004) observed that influence of pregnancy on AST activity in dry she- camels was negligible. However, there was a tendency to an increase in plasma $\mathrm{Zn}$ concentration in pregnant she-camel compared to those non-pregnant. Such increase in plasma Zn during pregnancy may relate of $\mathrm{Zn}$ to the role in fetal development and involution of the uterus (Ahmed et al., 2001).

Table 4. Mean $\pm \mathrm{SE}$ of Some blood plasma parameters of mature camels as affected by sex and pregnancy

\begin{tabular}{|c|c|c|c|}
\hline \multirow[t]{2}{*}{ Plasma parameters } & \multicolumn{3}{|c|}{ Physiological conditions } \\
\hline & Male & $\begin{array}{l}\text { Female dry not } \\
\text { pregnant }\end{array}$ & Female pregnant \\
\hline Total Protein, g/dl & $9.92^{\mathrm{a}} \pm 0.26$ & $7.92^{b} \pm 0.31$ & $8.01^{b} \pm 0.30$ \\
\hline Albumin, g/dl & $4.47^{\mathrm{a}} \pm 0.25$ & $3.07^{\mathrm{b}} \pm 0.31$ & $3.25^{\mathrm{b}} \pm 0.30$ \\
\hline Globulin, g/dl & $5.45^{\mathrm{a}} \pm 0.33$ & $4.85^{\mathrm{a}} \pm 0.39$ & $4.76^{\mathrm{a}} \pm 0.50$ \\
\hline $\mathrm{A} / \mathrm{G}$ ratio & $0.94^{\mathrm{a}} \pm 0.12$ & $0.69^{\mathrm{a}} \pm 0.14$ & $0.78^{a} \pm 0.10$ \\
\hline Glucose, $\mathrm{mg} / \mathrm{dl}$ & $64.88^{\mathrm{a}} \pm 2.90$ & $68.08^{\mathrm{a}} \pm 3.50$ & $69.51^{\mathrm{a}} \pm 5.20$ \\
\hline AST, RFU & $79.81^{\mathrm{a}} \pm 1.90$ & $82.82^{\mathrm{a}} \pm 2.20$ & $79.67^{\mathrm{a}} \pm 3.40$ \\
\hline ALT, RFU & $32.25^{\mathrm{a}} \pm 1.30$ & $30.00^{\mathrm{a}} \pm 1.6$ & $28.5^{\mathrm{a}} \pm 2.6$ \\
\hline $\begin{array}{l}\text { Total bilirubin, mg/dl } \\
\text { Mineral contents }\end{array}$ & $1.38^{\mathrm{a}} \pm 0.06$ & $1.33^{\mathrm{a}} \pm 0.07$ & $1.35^{\mathrm{a}} \pm 0.14$ \\
\hline $\mathrm{Ca}, \mathrm{mg} / \mathrm{dl}$ & $11.27^{\mathrm{a}} \pm 0.60$ & $10.71^{\mathrm{a}} \pm 0.70$ & $11.90^{\mathrm{a}} \pm 0.80$ \\
\hline $\mathrm{P}, \quad \mathrm{mg} / \mathrm{dl}$ & $5.70^{\mathrm{a}} \pm 0.28$ & $5.46^{\mathrm{a}} \pm 0.34$ & $5.22^{\mathrm{a}} \pm 0.40$ \\
\hline $\mathrm{Mg}, \mathrm{mg} / \mathrm{dl}$ & $2.02^{\mathrm{a}} \pm 0.10$ & $1.81^{\mathrm{a}} \pm 0.10$ & $1.74^{\mathrm{a}} \pm 0.15$ \\
\hline $\mathrm{Fe}, \quad \mu \mathrm{g} / \mathrm{dl}$ & $53.10^{\mathrm{a}} \pm 0.70$ & $49.70^{\mathrm{a}} \pm 0.80$ & $49.3^{\mathrm{a}} \pm 0.92$ \\
\hline $\mathrm{Cu}, \quad \mu \mathrm{g} / \mathrm{dl}$ & $65.00^{\mathrm{a}} \pm 1.20$ & $77.00^{\mathrm{a}} \pm 1.30$ & $85.00^{\mathrm{a}} \pm 2.00$ \\
\hline $\mathrm{Zn}, \quad \mu \mathrm{g} / \mathrm{dl}$ & $65.00^{\mathrm{a}} \pm 2.00$ & $69.00^{\mathrm{a}} \pm 2.30$ & $79.00^{\mathrm{a}} \pm 3.30$ \\
\hline
\end{tabular}

Means within the same row having different superscripts differ significantly $(\mathrm{P}<0.05)$

3-Effect of prolonged poor grazing and/ or chronic mange infection

Hematological parameters of peripubertal male camels as affected by prolonged poor grazing and/or chronic mange infection are given in Table 5. Blood TEC, Hb, $\mathrm{PCV}, \mathrm{MCH}, \mathrm{MCHC}$ and TLC were decreased $(\mathrm{P}<0.05)$ with prolonged poor grazing compared to normally fed camels (control). Further decrease occurred to these parameters except TLC where such prolonged poor grazing was associated with chronic mange infection. However, MCV value was not affected by such malnutrition.

Leukocytes differentiation indicated that $\mathrm{N}$ type was sharply decreased $(\mathrm{P}<0.05)$ when camels suffered from prolonged poor grazing or external parasite infection, with more pronounced decrease observed when poor grazing was associated with external parasite infection compared to the control. The reverse trend was observed for $\mathrm{E}$ and $\mathrm{M}$ types. $\mathrm{L}$ type increased $(\mathrm{P}<0.05)$ only when poor grazing was associated with external parasite infection. On the other hand, B type was not affected by the previous conditions.

Blood plasma biochemical constituents of peripubertal male camels suffered from prolonged poor grazing and/ or external parasite infection are given in table 6 . Exposure to poor grazing caused a remarkable decrease $(\mathrm{P}<0.05)$ in plasma total 
protein, albumin and globulin as to be only $60,48.1$ and $69.7 \%$, respectively of values observed in healthy- normally fed camels. Camels suffering from external parasite also showed a noticeable decrease in the same biochemical constituents but to a less severity. Moreover, camels suffering from prolonged poor grazing that associated with mange infection had a sever depression in blood plasma proteins. However, the $\mathrm{A} / \mathrm{G}$ ratio was decreased in camels suffering from nutritional and parasite stresses indicating that plasma albumin was negatively affected with higher magnitude than globulin. This is in agreement with Chaudhary et al. (2003), who reported that many of plasma proteins change markedly in disease conditions. They also reported that the major sits for plasma protein synthesis is the liver but also the immune system consisting of monocytes, macrophages, lymphoid and plasma cells.

Table 5. Mean $\pm \mathrm{SE}$ of Some hematological parameters of peripubertal male camels as affected by external parasite and/ or poor grazing

\begin{tabular}{lcccc}
\hline $\begin{array}{l}\text { Blood } \\
\text { parameters }\end{array}$ & \multicolumn{4}{c}{ Nutrition and health status } \\
\cline { 2 - 5 } & Control & Poor grazing & $\begin{array}{c}\text { External } \\
\text { Parasites }\end{array}$ & $\begin{array}{c}\text { Poor grazing + } \\
\text { Ex. Parasite }\end{array}$ \\
\cline { 2 - 5 } & $8.130^{\mathrm{a}} \pm 0.21$ & $6.863^{\mathrm{b}} \pm 0.15$ & $7.124^{\mathrm{b}} \pm 0.15$ & $5.472^{\mathrm{c}} \pm 0.20$ \\
\hline TEC x 10 & $10.93^{\mathrm{a}} \pm 0.31$ & $8.28^{\mathrm{b}} \pm 0.22$ & $10.85^{\mathrm{a}} \pm 0.22$ & $7.52^{\mathrm{c}} \pm 0.29$ \\
$\mathrm{Hb}$, g/dl & $26.98^{\mathrm{a}} \pm 0.90$ & $22.94^{\mathrm{b}} \pm 0.63$ & $29.35^{\mathrm{c}} \pm 0.63$ & $19.49^{\mathrm{d}} \pm 0.85$ \\
PCV \% & $33.30^{\mathrm{a}} \pm 1.18$ & $33.79^{\mathrm{a}} \pm 0.82$ & $41.10^{\mathrm{b}} \pm 0.82$ & $33.96^{\mathrm{b}} \pm 1.11$ \\
MCV, fl & $13.46^{\mathrm{a}} \pm 0.41$ & $12.25^{\mathrm{b}} \pm 0.29$ & $15.20^{\mathrm{c}} \pm 0.29$ & $13.06^{\mathrm{a}} \pm 0.38$ \\
MCH, pg & $40.50^{\mathrm{a}} \pm 0.63$ & $36.28^{\mathrm{b}} \pm 0.44$ & $37.15^{\mathrm{b}} \pm 0.44$ & $38.68^{\mathrm{c}} \pm 0.60$ \\
MCHC \% & $9.23^{\mathrm{a}} \pm 0.48$ & $8.90^{\mathrm{a}} \pm 0.33$ & $8.90^{\mathrm{a}} \pm 0.33$ & $10.44^{\mathrm{b}} \pm 0.46$ \\
TLC x 10 & & & & \\
TLC differentiation & & & \\
N \% & $42.69^{\mathrm{a}} \pm 1.5$ & $35.70^{\mathrm{b}} \pm 1.05$ & $37.30^{\mathrm{b}} \pm 1.05$ & $29.00^{\mathrm{c}} \pm 1.42$ \\
E \% & $5.13^{\mathrm{a}} \pm 0.41$ & $8.03^{\mathrm{b}} \pm 0.29$ & $7.42^{\mathrm{b}} \pm 0.29$ & $10.44^{\mathrm{c}} \pm 0.39$ \\
$\mathrm{~B} \%$ & $0.00^{\mathrm{a}} \pm 0.0$ & $0.15^{\mathrm{a}} \pm 0.06$ & $0.15^{\mathrm{a}} \pm 0.06$ & $0.06^{\mathrm{a}} \pm 0.08$ \\
M \% & $3.19^{\mathrm{a}} \pm 0.46$ & $5.79^{\mathrm{b}} \pm 0.32$ & $4.91^{\mathrm{b}} \pm 0.32$ & $7.72^{\mathrm{c}} \pm 0.43$ \\
L \% & $49.0^{\mathrm{a}} \pm 1.40$ & $50.3^{\mathrm{ab}} \pm 0.97$ & $50.21^{\mathrm{ab}} \pm 0.97$ & $53.06^{\mathrm{b}} \pm 1.31$ \\
\hline
\end{tabular}

Means within the same row having different superscripts differ significantly $(\mathrm{P}<0.05)$

Plasma glucose concentration of nutritionally stressed camels was decreased $(\mathrm{P}<0.05)$ as to be only $72.2 \%$ of the control camels (Table 6). Similar effect was observed in plasma glucose of camels suffering from only external parasite or combined stresses. This may indicate that camels are trying to exert a homeostatic regulation of their plasma glucose to maintain their beings.

Plasma AST and ALT activities and total bilirubin were elevated $(\mathrm{P}<0.05)$ as a response to poor grazing or external parasite infection. Plasma ALT activity was elevated by more than double as much as the normal level observed in control camels (Table 6). In addition the combined effect of both stresses (poor grazing and mange infection) caused further elevation in ALT activity. Both liver enzymes (AST $\&$ ALT) reflect the liver function which varies depending on the need of the animal for vital processes and condition of the liver to fulfill the different needs of the animal that eventually varied even in the healthy condition and also are indicative with stressed and diseased cases (Coles, 1986). 
Table 6. Mean \pm SE of Some blood plasma parameters of peripubertal camels as affected by parasite and/ or poor nutrition

\begin{tabular}{lcccc}
\hline Blood parameters & \multicolumn{4}{c}{ Nutrition and health status } \\
\cline { 2 - 5 } & Control & Poor grazing & $\begin{array}{c}\text { External } \\
\text { parasite }\end{array}$ & $\begin{array}{c}\text { Poor grazing }+ \\
\text { ex. Parasite }\end{array}$ \\
\hline Total Protein, g/dl & $9.92^{\mathrm{a}} \pm 2.8$ & $5.95^{\mathrm{b}} \pm 1.92$ & $6.69^{\mathrm{c}} \pm 1.92$ & $3.54^{\mathrm{d}} \pm 2.60$ \\
Albumin, g/dl & $4.47^{\mathrm{a}} \pm 2.5$ & $2.15^{\mathrm{b}} \pm 1.43$ & $2.69^{\mathrm{c}} \pm 1.43$ & $1.51^{\mathrm{d}} \pm 1.93$ \\
Globulin, g/dl & $5.45^{\mathrm{a}} \pm 2.0$ & $3.80^{\mathrm{b}} \pm 1.41$ & $3.97^{\mathrm{c}} \pm 1.41$ & $2.03^{\mathrm{d}} \pm 1.9$ \\
A/G ratio & $0.94^{\mathrm{a}} \pm .1$ & $0.67^{\mathrm{b}} \pm 0.07$ & $0.7^{\mathrm{ab}} \pm 0.07$ & $0.89^{\mathrm{ab}} \pm 0.09$ \\
Glucose, mg/dl & $64.88^{\mathrm{a}} \pm 3$ & $46.86^{\mathrm{b}} \pm 2.1$ & $55.40^{\mathrm{c}} \pm 2.10$ & $52.23^{\mathrm{bc}} \pm 2.79$ \\
AST, RFU & $79.81^{\mathrm{a}} \pm 3.8$ & $107.09^{\mathrm{b}} \pm 2.7$ & $98.06^{\mathrm{b}} \pm 2.7$ & $104.94^{\mathrm{b}} \pm 3.62$ \\
ALT, RFU & $32.25^{\mathrm{a}} \pm 2.7$ & $74.85^{\mathrm{b}} \pm 1.9$ & $72.61^{\mathrm{b}} \pm 1.90$ & $82.00^{\mathrm{c}} \pm 2.58$ \\
Total bilirubin, g/dl & $1.38^{\mathrm{a}} \pm .1$ & $1.71^{\mathrm{b}} \pm 0.05$ & $1.71^{\mathrm{b}} \pm 0.05$ & $1.87^{\mathrm{b}} \pm 0.06$ \\
Mineral contents & & & & \\
Ca, mg/dl & $11.27^{\mathrm{a}} \pm .7$ & $10.48^{\mathrm{a}} \pm 0.45$ & $10.45^{\mathrm{a}} \pm 0.45$ & $10.69^{\mathrm{a}} \pm 0.61$ \\
$\mathrm{P}, \mathrm{mg} / \mathrm{dl}$ & $5.70^{\mathrm{a}} \pm .3$ & $4.97^{\mathrm{a}} \pm 0.22$ & $5.27^{\mathrm{a}} \pm 0.22$ & $5.37^{\mathrm{a}} \pm 0.30$ \\
$\mathrm{Mg}, \mathrm{mg} / \mathrm{dl}$ & $2.02^{\mathrm{a}} \pm .13$ & $1.77^{\mathrm{a}} \pm 0.09$ & $1.75^{\mathrm{a}} \pm 0.09$ & $1.91^{\mathrm{a}} \pm 0.13$ \\
$\mathrm{Fe}, \mu \mathrm{g} / \mathrm{dl}$ & $53.1^{\mathrm{a}} \pm .37$ & $12.4^{\mathrm{b}} \pm .26$ & $39.5^{\mathrm{c}} \pm 0.26$ & $18.1^{\mathrm{d}} \pm 0.35$ \\
$\mathrm{Cu}, \mu \mathrm{g} / \mathrm{dl}$ & $65^{\mathrm{a}} \pm 0.1$ & $52^{\mathrm{a}} \pm 0.07$ & $57^{\mathrm{a}} \pm 0.07$ & $45^{\mathrm{a}} \pm 0.09$ \\
$\mathrm{Zn}, \mu \mathrm{g} / \mathrm{dl}$ & $64^{\mathrm{a}} \pm 0.11$ & $52^{\mathrm{a}} \pm 0.07$ & $41^{\mathrm{ab}} \pm 0.07$ & $24^{\mathrm{b}} \pm 0.10$ \\
\hline Means within the same row having different superscripts differ significantly $(\mathrm{P}<0.05)$
\end{tabular}

Plasma calcium, phosphorus, magnesium and copper tended to decrease as a response to both stresses (poor grazing and external parasite). Plasma iron was severely depressed in poorly grazed camels as to be only $23.4 \%$ of the normal value, similarly with the combined effectors.

Plasma zinc tended to decrease under either poor grazing or external parasite but it was severely depressed $(\mathrm{P}<0.05)$ when poor grazing was associated with external parasite as to be only $37.5 \%$ of the level observed in control camels (Table 6). In general, health status had a significant effect on the metabolic profile of camel (Faye et al., 1995)

\section{CONCLUSION}

Camel blood is a mirror of the physiologic or adverse conditions (age, sex, pregnancy, prolonged poor grazing, and chronic mange infection). All these effectors exert changes in the hematological and biochemical blood parameters. These changes could be used to monitor the normal physiologic and health status in camels in such situations. Keeping camel under human control (such as adequate nutrition and monitoring of physiological status and health) is very important for camel well being.

\section{REFERENCES}

Ahmed, M. M.; T. F. Hamed and M. E. Barri, 2001. Variation of zinc and copper concentrations in the plasma of Nubian goats according to physiological state. Small Ruminant Research, 39: 189-193.

Al-Qarawi, A. A.; H. A. Abdel-Rahman; M. S. El-Belely and S. A. El-Mougy, 2000. Age-related changes in plasma testosterone concentrations and genital organs content of bulk and trace elements in the male dromedary camel. Animal 
Reproduction Science 62: 297-307.

Bahram, D. and P. Trinder 1972. An improved colour reagent for the determination of blood glucose by the oxidase system. Analyst. 97: 142-145.

Bancroft, J.D., A. Stevens and D.R. Turner, 1996. Theory and practice of histological techniques. $4^{\text {th }}$ ed. Churchill Livingstone, New York, USA.

Benjamin, M.M., 1965. Outline of Veterinary Clinical Pathology. $1^{\text {st }}$ ed. New Delhi 110020. India.

Campbell, M.H., J.K. Miller and F.N. Schrick, 1999. Effect of Additional Cobalt, Copper, Manganese and Zinc on Reproduction and Milk Yield of Lactating Dairy Cows Receiving Bovine Somatotropin. Journal of Dairy Science. 82:1019- 1025.

Chaudhary, Z.I., J. Iqbal and J. Rashid, 2003. Serum protein electrophoretic pattern in young and adult camels. Australian Veterinary. 81: 625-626.

Coles, E.H., 1986. Veterinary clinical pathology. $4^{\text {th }}$ ed. Baillier, Tendal, London.

Doumas, B.T., W.A. Watson and H.G. Biggs, 1971. Albumin standards and the measurement of serum albumin with bromcresol green. Clinica Chimica Acta. 31: 87-96.

Duncan, D.B., 1955. Multiple range and multiple F tests. Biometrics 11:1-42.

FAO., 2001. Food and Agriculture Organization of the United Nations. FAO STAT online statistical service. FAO. http://www.fao.org

Faye, B., M. Ratovonanahary, J. P. Chacornac and P. Soubre, 1995. Metabolic profiles and risks of disease in camels in temperature conditions. Comparative Biochemistry and Physiology. 112: 67-73.

Feldman, B.F.; J.G. Zinkl and N.C. Jain, 2000. Schalm's Veterinary Hematology. Lippincott Williams \& Wilkins, Philadelphia, USA.

Frankle, S. and S. Reitman, 1963. Gradwash's Clinical Laboratory Methods and Diagnosis. Vol. (2). Hematology. Academic Press, London.

General Authority of Veterinary Services, 2004. Animal and poultry statistics, Ministry of Agriculture, Cairo, Egypt.

Henry, R.J., C.D. Cannon and J.W. Winkelman, 1974. A method for determination of plasma total protein. Clinical Chemistry: principles and techniques. Harper \& Raw, pp 415- 417. USA.

Mohamed, H.E., 2004. The zinc and copper content of the plasma of Sudanese Camels (Camelus dromedarius). Veterinary Research Communications, 28: 359363.

Netter, J., W.W. Wasserman and M.H. Kestener, 1985. Applied linear statistical model, regression, analysis of variance, and experimental designs. 2nd ed. Richard, D. Irwin, Home Wood, Illions, USA.

Rabagliati, D.S., 1924. The dentition of the camel. The Government Publications Office. Ministry of Finance, Cairo, Egypt.

Reitman, S. and S. Frankel, 1957. A colorimetric method for the determination of serum glutamic oxaloacetic and glutamic pyruvic transaminases. American Journal of Clinical Pathology. 28: 56-66.

Sarwar, A., M.A. Majeed, G. Hur and I.R. Khan, 2004. Two transferases and four electrolytes in normal one-humped camel serum. Journal of Camel Science 1:5761.

SAS, 1998. SAS user's guide for personal computers, SAS Institute Inc., Carry, NC, USA 
Sherlock, S., 1951. Liver Diseases, P. 204, Churchill, London.

Tietz, N.W., 1983. Clinical Guide to Laboratory Tests. W. B. Saunders \& Co., USA Wintrobe, M. M., G. Rich Lee, D.R. Boggs, T.C. Brithell, J.W. Athens and J. Forester, 1976. Clinical Hematology. $7^{\text {th }}$ ed. P. 26, Lea \& Fabiger, Philadelphia, USA.

Zoethout, W. D. and W.W. Tuttle, 1950. Textbook of Physiology. $10^{\text {th }}$ ed. The C. V. Mosby company, St. Louis, USA. 


\section{مكونات الام الهيماتولوجية والبيوكيميائية للجمال وحيدة السنام نتيجة لظروف فسيولوجية \\ وغذائية وطفيلية}

ياسين محمد حافظ

\section{قسم الإنتاج الحيوانسي، كلية الزراعة، جامعة القاهر، الجيزة، ج. م.ع}

أجريت ثلاث تجارب منفصلة باستخدام 46 جمل بغرض دراسة تأثثر بعض العوامل الفسيولوجية والغذائية

والطفيلية على خصائص الدم الهيماتولوجية والبيوكيميائية في الجمال .اشتملت التجربة الأولى على 18 18 اذكر

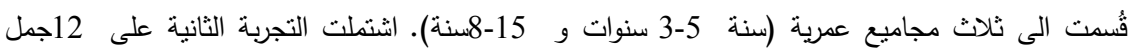

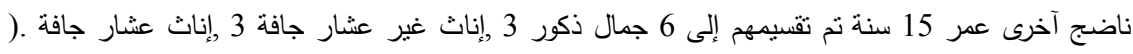

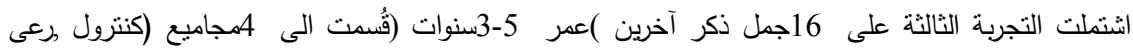

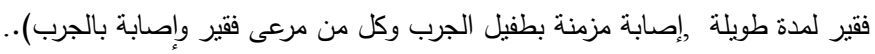

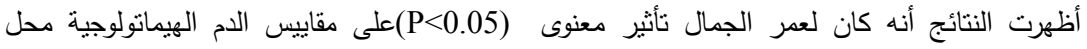

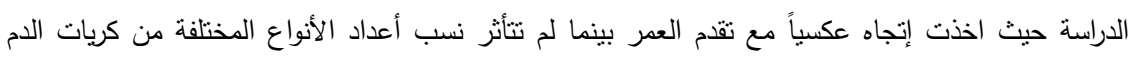

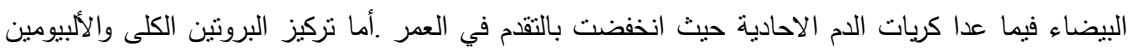

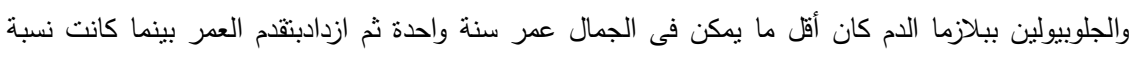

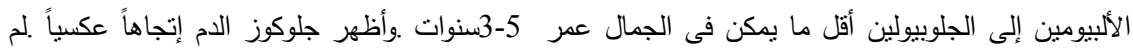
يتأثر نشاط إنزيمات الكبد (AST \& ALT)بالعمر بينما انخفض مسنوى البيليروبين الكلي بالثقدم في العمر. أظهر محتوى بلازما الدم من الدعادن أن الجمال صغيرة السن لديها أقل المستويات من الكالسيوم

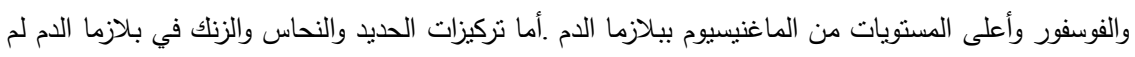
تتأثر معنوياً بالعمر.

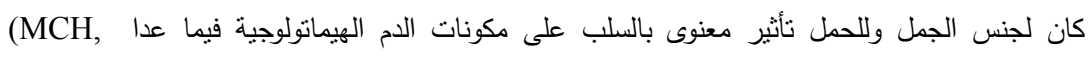

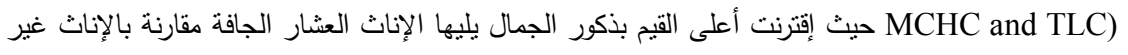

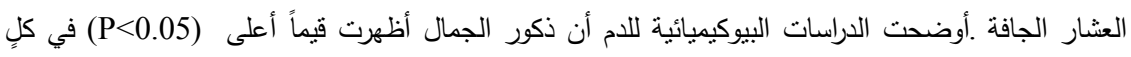
من البروتين الكلي والألبيومين من الإناث بينما لم يكن للحمل تأثير معنوي على مكونات الدم البيوكيميائية

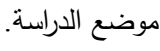

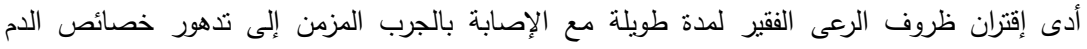

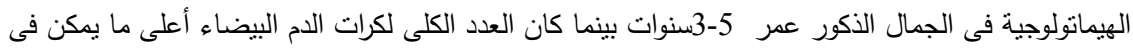

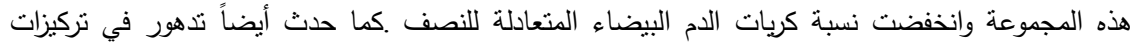

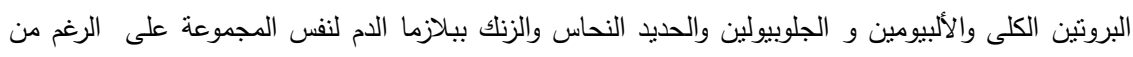

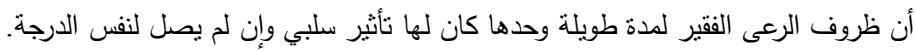

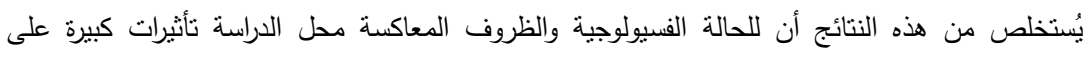

$$
\text { تركيب الدم هيماتولوجياً وبيوكيميائياً في الجمال. }
$$

